\title{
Study of Phosphate Formation on S355J2 HSLA Steel
}

Kamil Borko ${ }^{1}$, Filip Pastorek ${ }^{2}$, Stanislava Fintová ${ }^{3}$, Martina Neslušan-Jacková ${ }^{2}$, Branislav Hadzima $^{2}$

${ }^{1}$ Department of Materials Engineering, FME, University of Žilina, Univerzitná 8215/1, 01026 Žilina. Slovak Republic. E-mail: kamil.borko@fstroj.uniza.sk

${ }^{2}$ Research Centre, University of Žilina, Univerzitná 8215/1, 01026 Žilina.Slovak republic

${ }^{3}$ Institute of Physics of Materials, Academy of Sciences of the Czech Republic, v.v.i., Žižkova 22, 61662 Brno, Czech Republic

In present paper, the growth process of the phosphate coating on S355J2 steel was investigated. The microstructure, surface morphology, coating thickness, surface roughness and corrosion resistance of the phosphate coating were analysed by using several techniques including light microscopy, confocal laser scanning microscopy (CLSM) and electrochemical tests - electrochemical impedance spectroscopy (EIS) in $\mathrm{O.1M}_{2} \mathrm{Na}_{2} \mathrm{SO}_{4}$ solution (simulation of industrial atmosphere). The phosphate coating formation was evaluated after chosen exposure times from 15 minutes to 105 minutes in phosphating bath composed of $\mathrm{MnO}_{2}, \mathrm{H}_{3} \mathrm{PO}_{4}$ and demineralised $\mathrm{H}_{2} \mathrm{O}$. The optimal exposure time of $\mathrm{S355J} 2$ steel in selected phosphate solution was determined from surface quality, corrosion resistance and energy consumption point of view.

Keywords: steel S355J2, manganese phosphate, corrosion resistance

\section{Acknowledgement}

The research is supported by Science Grant Agency of the Slovak Republic through project No. 1/0720/14 and by European Regional Development Fund and Slovak state budget by the project "Research Centre of the University of Žilina”, ITMS 26220220183. Authors are grateful for the support in experimental works to Slovak Research and Development Agency by the project No. No. APVV-14-0772.

\section{References}

[1] HONG-LIANG DAI, TING DAI XIANG YAN. (2015). Thermoelastic analysis for rotating circular HSLA steel plates with variable thickness. Applied Mathematics and Computation. Vol. 268, Pages 1095-1109.

[2] TRSKO, L., BOKUVKA, O., NOVY, F., GUAGLIANO, M. (2014). Materials and Design. Vol. 57, Pages 103113.

[3] RAGU NATHAN, S., BALASUBRAMANIAN, V., MALARVIZHI, S., RAO, A.G. (2015). Defence Technology. Vol. 11, Pages 308-317.

[4] LIU, C. L., XIN, Y. C., TANG, G. Y. (2007). Materials Science and Engineering. A 456, Pages 350-357.

[5] KONAR, R., SVENTEK, M., BUCHA, B. (2016). Manufacturing Technology. Vol. 16, 2016. Pages 129-132.

[6] LAGO, J., GUAGLIANO, M., NOVÝ, F., BOKUVKA, O. (2016). Manufacturing Technology. Vol. 16, Pages 154-159.

[7] HAGANS, P., L., HAAS, CH., M. (1999). ASM Handbook, Vol. 5, Surface Engineering. Pages 405.

[8] GALVAN-REYES, C., FUENTES-ACEITUNO, J, C., SALINAS-RODRÍGUEZ, A. (2016). The role of alkalizing agent on the manganese phosphating of a high strength steel part 1: The individual effect of $\mathrm{NaOH}$ and NH4OH. In Surface and Coatings Technology. Vol. 291, Pages 179-188.

[9] BANCZEK, P., RODRIGUES, P., R., P., COSTA, I. (2008). Surface Coating Technology. Vol. 202, Pages 2008-2014.

[10] DÍAZ, B., FREIRE, L., MOJÍO, M., NÓVOA, X.,R. (2015). Optimization of conversion coatings based on zinc phosphate on high strength steels, with enhanced barrier properties. Journal of Electroanalytical Chemistry. Vol. 737, Pages 174-183.

[11] GALVAN-REYES, C., FUENTES-ACEITUNO, J, C., SALINAS-RODRÍGUEZ, A. (2015). Degradation and crystalline reorganization of hureaulite crystals during the manganese phosphating of a high strength steel. In Surface \& Coatings Technology. 275, Pages 10-20.

[12] WENG, D., JOKIEL, P., UEBLEIS, A., BOEHNI, H. (1996). Corrosion and protection characteristics of zinc and manganese phosphate coatings. In Surface and Coatings Technology. Vol 88, Pages 147-156.

[13] LORIN, G. (1973). La Phosphatation des Mbaux. Editions Eyrolles, Paris, France. 
[14] SANKARA NARAYANAN, T., S., N. (1996). Influence of various factors on phosphatability-An overview. In Metal Finishing. Vol. 94, Pages 86-90.

[15] ISO 4287-1997 Geometrical Product Specification - Surface Texture: Profile method - Terms definitions and surface texture parameters.

[16] MALSHE V.,C., and MEENAL SIKCHI. (2008.) Basics of Paint Technology Part 2. Antar Prakash Centre for Yoga, ISBN-13: 978-8190329842, Pages 624.

[17] EDWARD, L., GHALI, R., J., A., Potvin, (1972). The mechanism of phosphating of steel, Corros. Sci. 12 (1972) 583-594.

[18] SANKARA NARAYANAN, T., S., N. (2005). Advanced Materials Science. Vol. 9, Pages 130.

[19] GALVAN-REYES, C., FUENTES-ACEITUNO, J, C., SALINAS-RODRÍGUEZ, A. (2015). Degradation and crystalline reorganization of hureaulite crystals during the manganese phosphating of a high strength steel. In Surface \& Coatings Technology. Vol. 275, Pages 10-20.

[20] HADZIMA, B. - MHAEDE, M. - PASTOREK, F. (2014). Electrochemical characteristics of calcium-phosphatized AZ31 Magnesium alloy in $0.9 \% \mathrm{NaCl}$ Solution. In Journal of Materials Science: Materials in Medicine. ISSN 1573-4838, 2014, vol. 25, no. 5, Pages 1227-1237.

[21] WEI, B., TOKASH, J., C., ZHANG, F., KIM, Y., LOGAN, B., E. (2013). Electrochemical analysis of separators used in single-chamber, air-cathode microbial fuel cells. Electrochim Acta. Vol. 89, Pages 45-51.

[22] HAN, X., G., ZHU, F., ZHU, X., P., LEI, M., K., XU, J., J. (2013). Electrochemical corrosion behavior of modified MAO film on magnesium alloy AZ31 irradiated by high-intensity pulsed ion beam. Surface Coating Technology. Vol. 228, Pages 164-70.

[23] MHAEDE, M., PASTOREK, F., HADZIMA, B. (2014). Influence of shot peening on corrosion properties of biocompatible magnesium alloy AZ31 coated by dicalcium phosphate dihidrate (DCPD). In Materials Science and Engineering: C. ISSN 0928-4931, 2014, vol. 39, Pages 330-335.

[24] FRANKEL, G., S. (2008). Electrochemical techniques in corrosion: status, limitations, and needs, J. ASTM Int. 5, Pages 3-40, http://dx.doi.org/10.1520/JAI101241.

[25] ARIZA, E., ROCHA, L., A. (2005). Evaluation of corrosion resistance of multi-layered Ti/glass-ceramic interfaces by electrochemical impedance spectroscopy. Materials Science Forum. Vol. 492-493, Pages 189-194. 